Saudi Journal of Economics and Finance

Abbreviated Key Title: Saudi J Econ Fin ISSN 2523-9414 (Print) |ISSN 2523-6563 (Online)

Scholars Middle East Publishers, Dubai, United Arab Emirates

Journal homepage: http://saudijournals.com/sjef/

Original Research Article

\title{
Impact of Personal Factors on Tax Evasion: Comparative Analysis of Gender
}

Deden Tarmidi*

Universitas Mercu Buana, Jakarta, Indonesia

DOI: $10.36348 /$ sjef.2020.v04i01.004

| Received: 15.01.2020 | Accepted: 22.01.2020 | Published: 24.01.2020

*Corresponding author: Deden Tarmidi

\section{Abstract}

This study is a follow-up study of tax compliance study that has been done previously. The perspective of the taxpayer's perception of tax evasion is important to analyze apart from the perspective of the perception of tax compliance that has been done so far. The fact that tax revenue in Indonesia has not reached the target so far and the level of tax compliance that is less than optimal in Indonesia encourages researchers to analyze the factors that influence taxpayers to carry out tax evasion actions. As a theory reasoned action that a person's actions are influenced by internal factors of the person himself. Adopting previous studies, some internal factors analyzed in this study are Religiosity, Ethics, and Understanding of Taxation of Taxpayers then a comparative analysis of respondents' Gender is analyzed which effects on Tax Evasion are analyzed. SMEs in Pasar Tanah Abang were used as the unit of analysis for this study because of their status as Individual Taxpayers and personal traders in Pasar Tanah Abang. The results found that women's religious and ethical levels had a significant negative impact on tax evasion, while women's understanding had a positive impact on tax evasion. These results differ from the level of religious, ethical and understanding that men have that do not have a strong impact on tax evasion.

Keywords: Tax Evasion, Religiusity, Ethics, Understanding, Gender.

Copyright @ 2020: This is an open-access article distributed under the terms of the Creative Commons Attribution license which permits unrestricted use, distribution, and reproduction in any medium for non-commercial use (NonCommercial, or CC-BY-NC) provided the original author and source are credited.

\section{INTRODUCTION}

Tax revenue has an important role for the development of a country, especially for developing countries like Indonesia. Then the regulator needs to analyze all the factors that have a relationship with tax revenue to then be the basis in making policies so that the realization of revenue in accordance with the specified targets. Although various policies have been taken by the Directorate General of Taxes as the authorities in Indonesia, state revenue from year to year is always far from the target set by the Government.

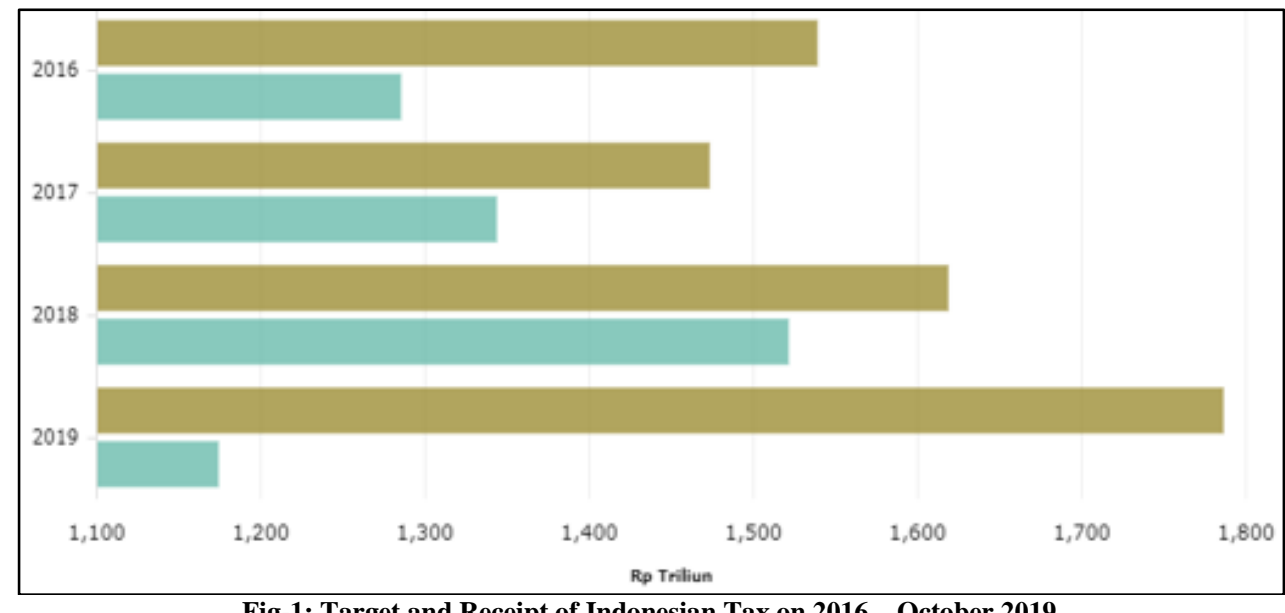

Fig-1: Target and Receipt of Indonesian Tax on 2016 - October 2019 
In figure 1 above it can be seen that the realization of tax revenue from year to year is not in accordance with the specified target, especially for 2019 which in the 10th month the amount of realization is very far from the 2019 revenue target that has been determined. The practice of tax evasion is considered as one of the actions that causes the realization of tax revenue is not optimal [1].

In recent years, information that is known as "Panama Paper" has been created, which contains the names of companies throughout the world (including Indonesia) who carry out tax avoidance practices by making fictitious transactions to store assets in Tax Heaven Countries [2]. In Indonesia, many motives are carried out by taxpayers in the practice of tax avoidance. The case of issuing and crediting fictitious tax invoices is one of the most common cases of tax evasion, as the commissioner of PT. SEP in Tangerang is detrimental to the country 19.6 billion Rupiahs [3].

Several factors are known to cause taxpayers to comply or carry out tax evasion, especially internal factors as explained in the theory of reasoned action. Sofha \& Utomo [4] and Surahman \& Putra [5] in their research found that one's religiosity has an impact on his ethics not to carry out tax evasion, while Basri [6] and Dharma et al. [7] found no religious influence on tax evasion. In addition to religiousity as an internal factor for taxpayers, ethics, knowledge and understanding of taxation are found to have a negative influence on tax evasion $[8,9,7,5]$.

Based on the background and research gap in previous studies, researchers conducted research by analyzing the influence of religious, ethical and understanding of taxpayers on tax evasion. The uniqueness of this research is the existence of comparative analysis based on the gender of the respondent, resulting in an in-depth discussion of the perceptions of female and male respondents on the analyzed variables.

\section{LITERATURE REVIEW \\ Theoritical Framework}

Theory of Reasoned Action proposed by Fishbein \& Ajzen [10] state that the intention to do something behavior is influenced by two factors: attitudes and subjective norms. Behavior a person does is influenced by individual factors owned by the person himself such as one's skills and ethics [11] in addition to other factors beyond the control of the individual. In this case the action of tax evasion is thought to be influenced by individual taxpayer factors, specifically the level of religious, ethical and understanding of taxation owned by the taxpayer.

Rahayu [12] defines tax evasion as an active effort of taxpayers in terms of reducing, eliminating, illegal manipulation of tax debt or escape from paying taxes as they are owed according to statutory regulations. This business method is illegal (unjustified business) carried out by taxpayers to escape or avoid taxation by carrying out irregular acts, ie minimizing tax payments, not reporting taxes in full or manipulating the amount of tax owed and various other forms of fraud committed on purpose and in a conscious state. This is a criminal offense because it is a violation of tax laws.

Basri and Surya [6] explain that religiosity is the religious values adopted by a person. All religions generally have the same goal in controlling good behavior and inhibiting bad behavior. Religion is expected to provide internal control for monitoring selfenforcement in moral behavior. Religiusity refers to the level of attachment of an individual to religion. This shows that the individual has lived and internalized the teachings of his religion so that it influences in all his actions and outlook on life.

Lawrence et al. [10] defines ethics as the concept of right or wrong of a behavior that tells us about morals and immorality, how we think and behave towards others and how we want them to think and behave towards us. From this understanding it can be seen that ethics is related to the concept of right or wrong, and ethical principles are demands to behave according to morals.

Understanding is the ability to capture the meaning and meaning of the material being studied [13]. Understanding taxation is the level of knowledge of rights and obligations as a taxpayer. It can be concluded, understanding taxation is a process where taxpayers understand and know about regulations and laws and taxation procedures and apply them to carry out taxation activities such as paying taxes, reporting tax returns, etc. And also knowing tax rates according to laws and benefits the tax they pay [5].

The level of understanding is higher than the level of knowledge, where taxpayers who understand information and taxation provisions automatically know about the information and taxation provisions. Conversely, taxpayers who only know the information and provisions of taxation do not necessarily understand what they know.

In his research, O'Hagan [14] found that women are better at leading companies because they are more powerful in control functions. In tax evasion actions, women are considered to be more able to control themselves, especially at the level of religious, ethical and taxation understanding they have.

\section{Conceptual Framework and Hypothesis Development \\ Religiusity is the level of depth of} understanding one's religion. Taxpayers who have a 
high level of religious understanding certainly understand that obeying state regulations as long as they do not conflict with religious rules is mandatory, so that tax evasion is not carried out. In line with the study of Sofha \& Utomo [4] and Surahman \& Putra [5] who found that the reliance of taxpayers had a negative influence on tax evasion.

\section{Hla. Religiusity owned by women negatively affect tax evasion \\ HIb. Religiusity owned by men negatively affects tax evasion}

Ethics is something that is owned by someone in distinguishing right from wrong so as to encourage him to do good things [11]. Taxpayers who have ethics certainly understand that the act of tax evasion is wrong because it is contrary to applicable regulations, thus encouraging it to avoid tax evasion. In line with Zirman's research [15] which found that ethics of taxpayers has a negative influence on tax evasion.

\section{H2a. Women's ethics have a negative effect on tax evasion \\ $H 2 b$. Men's ethics have a negative effect on tax evasion}

Taxpayers who have a good understanding of taxation rights and obligations are aware of the do's and don'ts of taxation obligations so that they help them to comply with taxes [16] and avoid tax evasion because of the consequences attached to these actions. In line with Dharma, et al. [7] and Surahman \& Putra [5] who in their research found that understanding taxation had a negative effect on tax evasion.

H3a. Understanding taxation owned by women has a negative effect on tax evasion

H3b. Understanding taxation owned by men negatively affects tax evasion

\section{METHODOLOGY \\ Population and Sample}

Traders (SMEs) in Pasar Tanah Abang were used as populations in this study, where the convenience sampling method was used to collect the data to be analyzed. From 1,155 traders in Block F Pasar Tanah Abang, 200 questionnaires with Likert 1-4 were distributed and 133 data were received back, but only 103 complete data were filled out by respondents who have NPWP.

\section{Operational Variable}

Tax evasion is the dependent variable in this study. Tax evasion in this study is defined as an attempt by taxpayers in order to ease the tax burden in a way that violates the law [7]. Developing tax provisions article 38 and article 39 of Law Number 28 Year 2007 concerning General Provisions and Tax Procedures and limitation of the analysis unit at the SMEs in Tanah Abang Market that already have NPWP, the tax evasion variable in this study was measured using 4 indicators namely not depositing taxes collected, do not deposit taxes properly, do not report actual income taxes, do not report taxes on time.

Religiosity in this study is defined as the level or religious values that a person has [6]. Adopting Rosianti [13] with a few modifications, the religiosity in this study was measured using indicators of trusting in God's supervision, trusting the consequences of deeds, obeying religious teachings, and observing practicing worship.

Tax ethics are the attitudes, actions and behavior of taxpayers to comply with tax regulations such as paying taxes. Adopting Tarmidi \& Waluyo [16] ethics in this study was measured using honest indicators in tax reporting, being honest in calculating taxes, not violating ethics, and carrying out the right actions.

Understanding Taxation is a higher level than just knowing tax information and procedures in accordance with applicable regulations. Adopting Rosianti [13] with a slight modification, understanding of taxation in this study was measured using indicators of calculating tax knowledge, tax deposit knowledge, tax reporting knowledge, understanding tax calculation, and understanding tax rates.

\section{Hypothesis Testing Method}

Using SmartPLS version 2 with the Structure Equation Model (SEM) approach, the data collected were analyzed for validity and reliability tests first and then conducted a regression test and comparative test based on the respondent's gender. 


\section{RESULT AND DISCUSSION}

Table-1: Statistic Descriptive

\begin{tabular}{|l|l|l|l|l|}
\hline \multicolumn{2}{|l|}{ Group } & Full & Male & Female \\
\hline $\mathrm{N}$ & & 103 & 69 & 34 \\
\hline \multirow{3}{*}{ RE } & Min & 1 & 1 & 1 \\
\cline { 2 - 5 } & Max & 4 & 4 & 4 \\
\cline { 2 - 5 } & Mean & 3,50495 & 348897 & 3,53788 \\
\hline \multirow{4}{*}{ ET } & Min & 1 & 1 & 1 \\
\cline { 2 - 5 } & Max & 4 & 4 & 4 \\
\cline { 2 - 5 } & Mean & 3,18069 & 3,12868 & 3,28788 \\
\hline \multirow{3}{*}{ UN } & Min & 1 & 1 & 1 \\
\cline { 2 - 5 } & Max & 4 & 4 & 4 \\
\cline { 2 - 5 } & Mean & 3,19806 & 3,20290 & 3,18824 \\
\hline \multirow{3}{*}{ TE } & Min & 1 & 1 & 1 \\
\cline { 2 - 5 } & Max & 4 & 4 & 4 \\
\cline { 2 - 5 } & Mean & 2,09653 & 2,16176 & 1,96212 \\
\hline
\end{tabular}

From table 1 it can be seen that the level of respondents' religiosity is high with an average value of around 3.5 from scores 1-4 while the ethical level and understanding of respondents is quite high with an average value of 3 from scores 1-4. Respondents' perceptions of tax evasion actions are quite good where the average respondent disagrees with tax evasion actions with a score of 2 from a given score of 1-4.

Table-2: Goodfit Analysis

\begin{tabular}{|l|l|l|l|}
\hline Variable & R-Square & AVE & Composite Reliability \\
\hline RE & & 0,788 & 0,933 \\
\hline ET & & 0,648 & 0,784 \\
\hline UN & & 0,603 & 0,856 \\
\hline TE & 0,155 & 0,663 & 0,887 \\
\hline
\end{tabular}

With AVE amount above 0.5 this research data is valid, whereas with composite reliability values above 0.7 this data is reliable, while the r-square value of 0.155 explains that the research model consisting of religious, ethical and understanding taxation explains tax evasion by $15.5 \%$.

Table-3: Regression and Comparative

\begin{tabular}{|c|c|c|c|c|c|c|c|c|c|}
\hline \multirow[t]{2}{*}{ Variable } & \multicolumn{3}{|c|}{ All } & \multicolumn{3}{|c|}{ Male } & \multicolumn{3}{|c|}{ Female } \\
\hline & $\begin{array}{c}\text { original } \\
\text { sampel } \\
\text { estimate }\end{array}$ & t-stat & t-table & $\begin{array}{c}\text { original } \\
\text { sampel } \\
\text { estimate }\end{array}$ & t-stat & t-table & $\begin{array}{c}\text { original } \\
\text { sampel } \\
\text { estimate }\end{array}$ & t-stat & t-table \\
\hline $\mathrm{RE}$ & $-0,122$ & 0,684 & 1,290 & $-0,203$ & 0,816 & 1,295 & $-0,267$ & $3,209 * * *$ & 2,457 \\
\hline ET & $-0,293$ & $1,635^{*}$ & 1,290 & 0,070 & 0,276 & 1,295 & $-0,492$ & $3,861 * * *$ & 2,457 \\
\hline $\mathrm{UN}$ & 0,379 & $1,753 *$ & 1,290 & 0,288 & 0,974 & 1,295 & 0,518 & $4,531 * * *$ & 2,457 \\
\hline Observation & & & 103 & & & 69 & & & 34 \\
\hline
\end{tabular}

Based on table 3, it can be explained that overall one's religiosity has a negative impact on tax evasion even though it is only on female respondents that the impact of religiosity is very strong on tax evasion. With these results meaka hypothesis $1 \mathrm{~b}$ rejected while hypothesis 1a accepted. These results explain that a person who has a high level of religiousity is someone who complies with the provisions including tax provisions so that they will not take action on tax evasion. This is in line with Sofha \& Utomo [4] and Surahman \& Putra [5] who also found a negative influence of religiosity on tax evasion.

Based on table 3 also can be explained that overall a person's ethics has a negative impact on tax evasion even though only on female respondents the impact of ethics is very strong on tax evasion. These results explain that hypothesis $2 \mathrm{~b}$ was rejected while hypothesis $2 \mathrm{a}$ was accepted. The higher the ethics a person has, all the actions he does will be taken care of so as not to conflict with applicable regulations. In this case, taxpayers who have high ethics tend not to carry out tax evasion because they realize that the activity is not good and contrary to the provisions. Although in this study, the influence of ethics owned by men is not too significant compared to the ethics that women have on tax evasion actions. This result is in line with the research of Zirman [15] which found a negative influence of taxpayer ethics on tax evasion.

Based on table 3, it can be explained that overall a person's level of understanding has a strong positive impact on tax evasion for both female and male 
respondents. These results explain that hypothesis $3 \mathrm{a}$ and hypothesis $3 \mathrm{~b}$ were rejected. These results explain that the more taxpayers understand taxation, the higher the tax evasion action. This indicates that taxes are still seen as a burden for taxpayers, especially MSMEs that reduce their assets so that evasion measures will actually be higher when taxpayers understand the prescribed taxation procedures and take advantage of unspecified loopholes to reduce tax burdens. These results contradict Dharma, et al. [7] and Surahman \& Putra [5] who in their research found that understanding taxation had a negative effect on tax evasion.

\section{CONCLUSIONS \& SUGESTIONS}

are as follows:

Some conclusions from the discussion above

- The level of religious and ethics of women has a strong negative influence on tax evasion while the level of religious and ethics of men has a weak influence. These results provide input for the government in minimizing tax evasion by creating programs or policies that can improve the level of religious and ethical community.

- The level of understanding of taxation has a positive effect on tax evasion. Even so, it does not mean that the government reduces tax socialization, because even though in Indonesia a self-assessment system applies, uneven information can cause losses for taxpayers.

\section{ACKNOWLEDGMENT}

This is a pilot study of research on tax evasion that is influenced by internal and external factors of taxpayers. We would like to thank all those who supported this research, both academic team of Universitas Mercu Buana, the SME respondents and the manajer of Pasar Tanah Abang, Jakarta.

\section{REFERENCES}

1. Salebu, J.T. (2019). Mengukur Kinerja Penerimaan Pajak 2019. Download from https://www.ssas.co.id/mengukur-kinerjapenerimaan-pajak-2019/

2. Ihsanuddin. (2016). Panama Papers yang Tak Pernah Mengguncang Indonesia. Download from https://nasional.kompas.com/read/2016/06/17/1958 4921/

panama.papers.yang.tak.pernah.mengguncang.indo nesia?page $=$ all

3. Utama, M.S. (2015). Ditjen Pajak Serahkan Tersangka Kasus Penggelapan Pajak Rp.19,6 Miliar ke Kejaksaan. Siaran Pers Direktorat Jenderal Pajak Kementrian Keuangan

4. Sofha, D., \& Utomo, S.D. (2018). Keterkaitan Religiusitas, Gender, LOM dan Persepsi Etika Penggelapan Pajak. Jurnal Ilmu Manajemen dan Akuntansi Terapan, 9(2), 43-61
5. Surahman, W., \& Putra, U.Y. (2018). Faktor-faktor Persepsi Wajib Pajak Terhadap Etika Penggelapan Pajak. Jurnal REKSA: Rekayasa Keuangan, Syariah, dan Audit, 5(1), 1-10

6. Basri, Y.M. (2015). Pengaruh Gender, Religiusitas Dan Sikap Love of Money Pada Persepsi Etika Penggelapan Pajak Mahasiswa Akuntansi. Jurnal Ilmiah Akuntansi dan Bisnis, 10(1), 45-54

7. Dharma, L., Agusti, R., \& Kurnia, P. (2016). Pengaruh Gender, Pemahaman Perpajakan dan Religiusitas Terhadap Persepsi Penggelapan Pajak. Jurnal Online Mahasiswa Fakultas Ekonomi, 3(1), 1565-1578

8. Dewi, N.K.T.J., \& Merkusiwati, N.K.L.A. (2017). Faktor-Faktor yang Mempengaruhi Persepsi Wajib Pajak mengenai Etika atas Penggelapan Pajak (Tax Evasion). E-Jurnal Akuntansi Universitas Udayana, 18(3), 2534-2564

9. Putri, H., Tanjung, A.R., \& Azhari, S. (2017). Pengaruh Sistem Perpajakan, Diskriminasi, Kepatuhan dan Pengetahuan Perpajakan Terhadap Persepsi Wajib Pajak Mengenai Etika Penggelapan Pajak (Studi Empiris pada Wajib Pajak Orang Pribadi di Wilayah Kota Pekanbaru). Jurnal Online Mahasiswa Fakultas Ekonomi, 4(1), 2045-2059

10. Fishbein, M., \& Ajzen, I. (1975). Belief, Attitude, Intention and Behavior. Addison-Wesley Lawrence, Anne T. \& Weber, James.(2008). Business \& Society: Stakeholders, Ethics, Public Policy (12th ed). New York: McGraw-Hill.

11. Tarmidi, D. (2019). Tax Compliance: Impact of Employee Internal Factors, Moderated by Tax Uncertainty. International Journal of Academic Research Business and Social Sciences, 9(5), 294304. DOI:10.6007/IJARBSS/v9-i5/5859

12. Sarpingah, S., Sormin, F., \& Handayani, R. (2017). Influence of Taxation Knowledge and Socialization of Imlementation PP. 46 Year 2013 on Tax Compliance for Certain WPOP Small and Medium Business (UMKM) Owner (Case Study in KPP Pratama Cengkareng, West Jakarta). Research Journal of Finance and Accounting, 8(22), 128-136

13. Tarmidi, D., \& Waluyo. (2014). Faktor-Faktor yang Mempengaruhi Kepatuhan Pajak, Dengan Pendekatan Perilaku dan Etika (Studi Empiris Pada Perusahaan PMA Yang Terdaftar Di Kanwil DJP Jakarta Khusus). TEKUN: Jurnal Telaah Akuntansi dan Bisnis, 5(1), 49-68

14. O'Hagan, A. (2017). Gender budgeting in Scotland: A work in progress. Administration, 65(3), 17-39.

15. Zirman. (2015). Pengaruh Penegakan Hukum dan Gender Terhadap Penggelapan Pajak Dimediasi oleh Moral Pajak. Akuntabilitas, VIII(2), 133-147

16. Tarmidi, D., Mayangsari, S., \& Khomsiyah. (2019). Analysis of Personality Tax Professional on Earnings Management. Religación. Revista de Ciencias Sociales y Humanidades, 4(17), 517-526. 